\title{
Technological Intervention for Effective Strategies Formulation and Implementation
}

\author{
Rutuja Deshmukh Jagtap, D.P. Singh, Ekta Singh, Pramod Shinde, Aparna Dixit
}

\begin{abstract}
City development plans i.e. master plans and planning strategies are conventional tools which has been historically used for city planning. However it is realized that the process of implementation has been neglected vis-à-vis formulation. This research emphasis on the significant gap between implementation of city Development plan and its integration with Advance Technological tools and engineering processes. The paper looks into key indications from past documentation and studies on implementation strategies and intervention of technological tools with respect to issues of city development plans. The review of collection of 131articles represents a valuable research contribution and development in the related field. Constructed on these findings, three research areas of potential interests are identified.

This paper puts forth research based findings on execution methodology with integration of technological tools like GIS, MIS, APS and strategies for effective implementation than to formulating which is missing in city development planning over a period
\end{abstract}

Keywords: technological tools, implementation, policies, strategy, execution, urban, development planning.

\section{INTRODUCTION AND BACKGROUND}

City management, internationally faces important issues and challenges due to population and rapid urban growth, After the Second World War, the land demand for urbanisation has grown at a fast rate, prompting governing authorities in many emerging countries to focus strategies regarding land in cities for sustainable and planned urban growth. Government of India, in 1969, introduced development plans as strategies to establish planned development and improved governance as per the Town and Country Planning Act 1966. Master Plan is the most common tools of development plan in India. According to Tiwari (2002), the development plan is application method of planning, production and resources. Master plan aims at improving the urban life and largely governs the efficiency level of human settlements.

Revised Manuscript Received on April 25, 2020.

* Correspondence Author

Rutuja Deshmukh Jagtap*, School of Architecture, Urban Development \& Planning, Symbiosis Skills \&Professionals University, Pune, India. Email: rutujad11@gmail.com

D.P.Singh, Architecture \& Planning Department, AMITY University,Noida, Delhi,India. Email: dpsingh@amity.edu

Ekta Singh, School of Design, AMITY University,Noida, Delhi,India,. Email: esingh@amity.edu

Dr.Pramod Shinde, School of Planning \&Architecture,JNIAS,Hyderabad ,India, Email:drpramodsshinde@gmail.com

Dr.AparnaDixit,Architecture,MMCA,Pune,India,Email:aparnavivekdix it@gmail.com

(C) The Authors. Published by Blue Eyes Intelligence Engineering and Sciences Publication (BEIESP). This is an open access article under the CC BY-NC-ND license (http://creativecommons.org/licenses/by-nc-nd/4.0/)
This system of planning master and development plans is based on long term, typically for a period of 20-25 years. In the process, it is assumed that adequate resources either exist or can be mobilized by the concerned urban local governments with the help of eminent domain legislation. There are various mechanisms available for comprehensively implementing the development plans. These mechanisms are zonal plans, land use specification, development control and planning for infrastructure provision.

As per Meshram (2006), there are many instances of nonimplementation of plans and delays due to the long and tedious procedures of the development cycle.

Over the years, it has been researched and found that barriers to implementation of development plan, the topic remains same due to rapid growth of the urban areas and the growing limitations and changes in land use over time.

However, the literature on development is quite divided and it is challenging to highlight the gaps that need to be looked into.

An early evaluation in our studies displayed the shortage of a overall and stepwise analysis of the literature that brings together the information and review of issues that are important to the discipline's development. This paper includes a description of most subjects and overtime of their evolution. Almost all of the policies, long research papers, guidelines, government publications are studied. Information from 131 papers and reports published in important publications between 1996 to 2017 is gathered. The inputs that affect the development of cities also are the focus of discussion.

\section{RESEARCH AIM}

Various factors and insufficient implementation policies affect the efficiency of development plans. Some papers specialize in definite topics or key aspects, than others. The study is based on exploration of the secondary data collected by revisiting the International Theoretical and Research Studies and reports from the Indian Government and other scholarly reports. As an example, Deborah Thomas (2001) focus on amendment of plans and policies while Donald McLeod et al. (2003) discuss about the need of inclusiveness and transparency for effective land use planning. Some papers focus on Financial and legal problems that hinder the implementation (Dejene Mulugeta, 2005), whereas others explore the insufficient implementation strategy and need to improve urban governance (Yang Li1 et al., 2008; Chetan Vaidya, 2009). Study show that problems in execution resulted in the nonaccomplishment of the certain goals of the development plans. In order to

Published By:

Blue Eyes Intelligence Engineering \& Retrieval Number: D9016049420/202
DOI: 10.35940/ijeat.D9016.049420

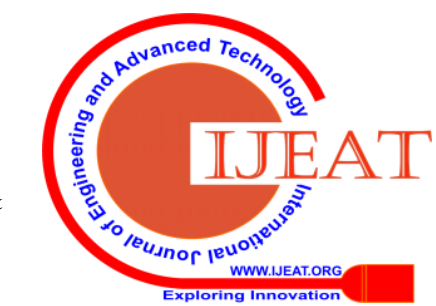


have a systematic identification of the barriers, in reference to time and stages of development, an exhaustive review of the existing studies is done. The present study limits to the review of secondary literature pertaining to legal and economic factors impacting the urban policies in developed and developing countries.

All collected data is analyzed to get findings of the research in respect to the framed objectives, as discussed below. Consequences provide insight that less research attention has been paid to formulation than to implementatiom Following is the question discussed in the research study of the paper -

1. Which aspects are the key focus of the discussion in the paper and its progression over the years?

The literature shows major different approaches in the different case studies , Robert Hrelja, 2015; Tom Goodfellow, 2012) to survey and stated preferences (Catharine Ward Thompson, 2002; Peter Istvan et al.2011). It has never been realized that certain methodologies better suit certain topics. Insightful insights are shown by analysis about the best methods when dealing with a topic, or it can recognize which methodologies are essential to provide a comprehensive overview of a subject. The other question is Q2. Which types of research methodologies are extensively used and their relation to the topics of research?

The third question of research is:

Q3.Which papers actually contribute to the literature base? To gain answers for the stated research questions the SLR was conducted with critical focuses aim and with consideration of other methods of improvisation.

This paper classifies different papers in the pool of literature base and thus the analysis gave the answers to the research questions.

Majority of findings from the pool of papers helped to identify the main topics addressed and its progression.

Analysis of the methodologies and themes used highlighted the future possibilities of research studies to find answers to research question 2 and 3.

\section{RESEARCH METHOD}

The literature review method is selected to understand the research questions and identify the gaps in research.
Emerging topics are also reviewed such as the Mechanism for procurement of base maps (Shanghai, World Exposition Executive Committee, 2010),

Behavior change, patriotism and progressive reduction of corruption (National Development Plan - Uganda, 2010), and review and modification of the land policies and legal system so as to facilitate simplification (URDPFI Guidelines, 2014).

A review earns the adjective "systematic" if its supported clearly framed questions, identifies relevant studies, reviews their quality and summaries the evidence by use of clear methodology (Khan et al., 2003). The stepwise documentation in the literature review helps in evaluation of the conducted study.

\section{Aspect for consideration}

Keywords were initial listed and requirements for inclusion was developed. The definition of implementation of the development plan was phrased with key words such as execution, operation, strategy, amendments to make a comprehensive studies (Wong et al., 2015).

Papers discussing biodiversity, climate change, ecosystem, smart city were excluded from the corpus so as to gain the consistency between the selected sources and themes.

Moreover, the research focused on long research papers, guidelines, government publications, policy framework, published refereed journals for the period 1996 to 2017. Even though Planning and Development Acts (T. \& C.P. Act, 1966) were formed in 1960's the major push in the literature began in 90's after the liberalization phenomena in India.

The search was focused a first set of criteria. Documents on Government documents policies guidelines with major publishers databases such as Emerald, Springer, Science Direct and Elsevier They were chosen for analysis. Control tests to check and refine the selection criteria was conducted on 40 papers (Tranfield et.al., 2003).

Every author selected specific articles manually to check for consistency with the including criteria. Criteria for inclusion / exclusion have been discussed and discussed until specific measures have been established. This helped to formulate the Table I. The question was re- reviewed.

Table I. Inclusion Report for paper selection

\begin{tabular}{|l|l|}
\hline $\begin{array}{l}\text { Aspects for } \\
\text { including }\end{array}$ & Particulars \\
\hline Important words & $\begin{array}{l}\text { execution, strategy, execution, urban plans, development, amendments, acts, planning, } \\
\text { policies, implementation }\end{array}$ \\
\hline Language & English \\
\hline Document types & Research papers, publications, Working Papers, Reports, Policies, Guidelines \\
\hline Source types & $\begin{array}{l}\text { research papers, guidelines, government publications, policy framework, published } \\
\text { refereed journals }\end{array}$ \\
\hline Time interval & $1996-2017$ \\
\hline
\end{tabular}




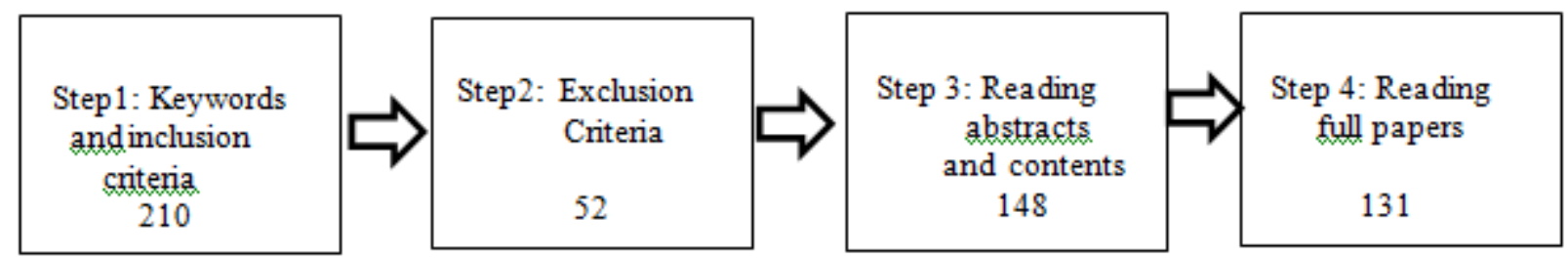

Figure 1 Systemic literature reviews tests according to procedure of collection

\section{Step 2: exclusion criteria}

52 papers concentrated on topics such as biodiversity, environment, smart city and papers that followed a strategy other than implementing the development plan were outside the reach of the study and excluded from the corpus.

\section{Step 3: Abstract based selection}

Each investigator reviewed the titles and abstracts of 148 pa pers selected. After a discussion with

the authors, papers were removed from out of the research $s$ cope. The abstracts and contents of selected papers were reviewed

Step 4: selection based on full text and snowballing Some descriptive statistics were first performed taking into account the corpus of 131 papers.

The papers were classifies with reference to the papers based on the topics and methodological approaches was performed to answer RQ1 and RQ2. Finally, to respond to RQ3, some often cited papers and literature chronology was performed to highlight the strength of the development and provide a dynamic perspective of quotations.

\section{ANALYSIS}

The distribution of papers in the corpus by year is shown in Figure 2. Given some differences in the time period considered, the steady addition of comments regarding the execution of development plans over the last ten years can be appreciated, thereby confirming the topic's current relevance.

The increase in the number of papers in 2015-2017 is partly due to the paradigm shift in the urbanization cycle in India and around the world with the introduction of urban department policies and schemes such as Jnnurm, Smart Cities, Amrut etc. Certain articles contained evidence to speed up the process of formulating a plan streamlined planning methods, principles and criteria for designing social and physical facilities with necessary modifications. (Directives on URDPFI, 2015)

All in all, our corpus includes various newspapers, government policies, statutes, and guidelines, and there is no dominant newspaper, even though urban development plans are mainly discussed by newspapers that concentrate on urban policy and regulation as their main research topic. Notwithstanding this, the collection also contains papers that concentrate on the field of government, management, law, and planning.

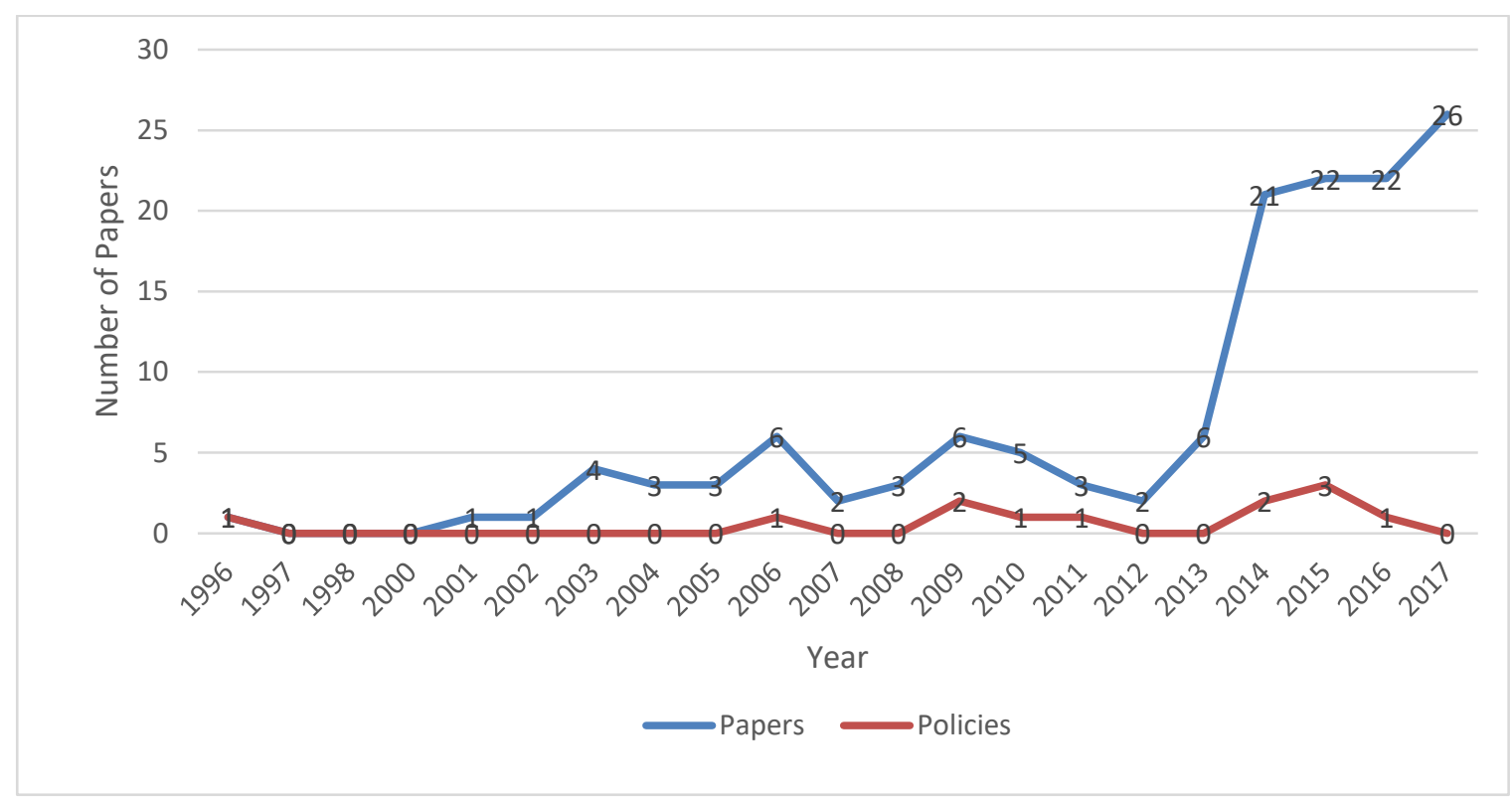

Figure 2: Distribution of articles by publication year

Published By:

Blue Eyes Intelligence Engineering \&

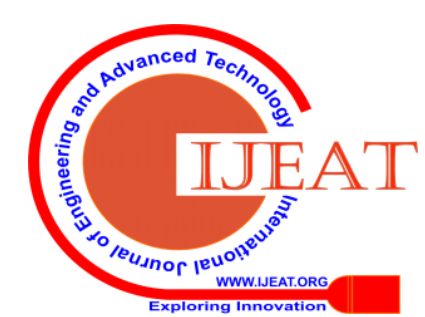




\section{CLASSIFICATION OF THE PAPERS}

Table II reports the results of the identification of the topics. Figures displays the fluctuations of the various topics as they appeared in the articles.

It was found that most papers address multiple topics.

The three subjects most discussed were as follows and Table II tabulates the topics.

Most discussed topics were:

(1) Mismatch between Space of Growth and Changing needs of the Society : Insufficient implementation strategy leads to Inadequate strategy formulation (Yang Li1 et.al.,2008)
(2) Lack of Coordination between Various Agencies: Data collection, compilation, legal challenges and various aspects are time consuming process (D.S.Meshram,2005; Ramakrishna Nallathiga 2009)

(3) Lack of monitoring mechanism: As need of monitoring efforts and its potential to contribute linkages between policy and plans several papers describe how strategic evaluation of land use change over time is needed(e.g. Catharine Ward Thompson.,2002; National Development Plan Uganda ,2010).

Table II: Table Themes in the Body of Paper

\begin{tabular}{|c|c|c|}
\hline Topic & Description & Paper \\
\hline $\begin{array}{l}\text { Lopsided Plan } \\
\text { Implementation }\end{array}$ & Unplanned growth & $\begin{array}{c}01,06,08,31,32,34,35,44,52,54,59,60,87,92 \\
, 99,106,127\end{array}$ \\
\hline $\begin{array}{l}\text { Lack of Monitoring } \\
\text { Mechanism }\end{array}$ & $\begin{array}{l}\text { Improvement in policies include amending act on } \\
\text { land use }\end{array}$ & $\begin{array}{c}10,12,17,32,34,46,54,59,60,73,77,87,89,90 \\
, 92,99,106,122,125,127\end{array}$ \\
\hline Time Consuming Process & Delay in DP finalization and implementation & $12,13,31,32,35,44,59,92,106,121,127$ \\
\hline $\begin{array}{l}\text { Rigid Process of } \\
\text { Modification /Revisions }\end{array}$ & $\begin{array}{l}\text { Changes should be considered while carrying out } \\
\text { the development control function as they display } \\
\text { the requirements for improvements to Planning } \\
\text { Policies }\end{array}$ & $\begin{array}{c}07,26,27,32,33,37,51,68,79,84,87,92 \\
102,105,106,115,125,127\end{array}$ \\
\hline $\begin{array}{l}\text { Lack of Coordination } \\
\text { between Various Agencies }\end{array}$ & $\begin{array}{l}\text { Strengthening of } \\
\text { bodies responsible for the planning and managem } \\
\text { ent of land use. }\end{array}$ & $\begin{array}{l}01,06,07,08,10,16,17,18,19,24,25,29,30,32 \\
, 34,35,44,52,54,60,65,69,79,87,90, \\
102,103,106,118,127\end{array}$ \\
\hline $\begin{array}{l}\text { Lack of Investment } \\
\text { Strategies }\end{array}$ & $\begin{array}{l}\text { Formation of cooperation partnership frame for } \\
\text { the increase of action capacity and institutional } \\
\text { development }\end{array}$ & $\begin{array}{c}01,12,16,19,24,25,29,35,36,44,45,46,52 \\
60,65,69,79,90,99,106,107,109,127\end{array}$ \\
\hline $\begin{array}{l}\text { Ineffective Public } \\
\text { Participation }\end{array}$ & $\begin{array}{l}\text { Decision making through participation of the } \\
\text { Public for improved governance and } \\
\text { implementation. }\end{array}$ & $\begin{array}{c}02,11,15,24,35,36,45,61,64,65,94,106, \\
115,127\end{array}$ \\
\hline $\begin{array}{l}\text { Weak Data Base and Non } \\
\text { Availability of Base Maps }\end{array}$ & Mechanism for procurement of base maps & $22,25,106,127$ \\
\hline Prescription of Land Uses & $\begin{array}{l}\text { Strategic evaluation of land use change over time } \\
\text { is needed }\end{array}$ & $03,04,36,48,106,127$ \\
\hline Population Projection & $\begin{array}{l}\text { Disaggregation of regional demographic and } \\
\text { socio-economic information future urban growth }\end{array}$ & $10,20,106,127$ \\
\hline $\begin{array}{l}\text { Lack of Emphasis on } \\
\text { Environmental Parameters }\end{array}$ & $\begin{array}{l}\text { Low awareness and results in weak influencing } \\
\text { strategy implementation }\end{array}$ & $47,55,56,58,72,73,95,100,127,130$ \\
\hline $\begin{array}{l}\text { Mismatch between Space } \\
\text { of Growth and Changing } \\
\text { needs of the Society }\end{array}$ & $\begin{array}{l}\text { Approach and new insight to growth of space and } \\
\text { usage considering human needs and ecological } \\
\text { framework is required }\end{array}$ & $\begin{array}{l}04,08,09,11,13,14,21,23,25,27,28,30,34,39 \\
, 40,41,42,43,47,49,50,56,57,63,67,71,76,7 \\
9,80,81,85,88,94,97,98,99,100,105,106,10 \\
\text { 8,113,114,116,119,120,123,127,1 } \\
\text { 28,129,130,132, }\end{array}$ \\
\hline $\begin{array}{l}\text { Neglect of development of } \\
\text { urban fringe }\end{array}$ & $\begin{array}{l}\text { Inclusion of experts and brokers } \\
\text { in knowledge translation at implementation plann } \\
\text { ing committees }\end{array}$ & $16,22,62,75,101$ \\
\hline $\begin{array}{l}\text { Absence of National and } \\
\text { Regional Goal Priorities }\end{array}$ & Norms and objective to be governed & 19,117 \\
\hline
\end{tabular}




\begin{tabular}{|l|l|l|}
\hline Monitoring System & $\begin{array}{l}\text { Linkages between the higher level policy and its } \\
\text { intermediate plans for ultimate outcome }\end{array}$ & $05,53,66,70,74,78,82,83,86,93,110,111$ \\
\hline
\end{tabular}

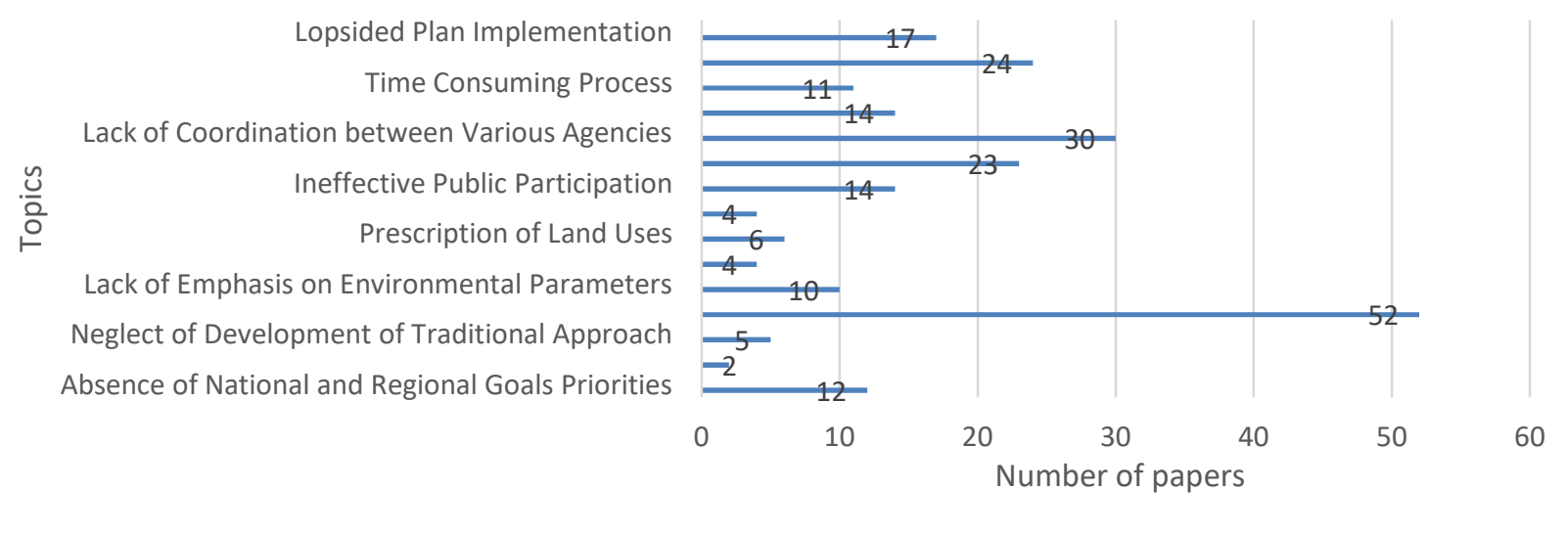

Figure 3: Number of papers addressing each topic

Note: Each paper may refer to more than one topic

\section{REVIEW OF SUBJECTS AND THEIR REFERENCE}

Research stress on the different topics has shifted through the years . When the review was conducted (1996 to 2002), only certain subjects were discussed, such a s, lack of coordination, amendment of plan and policies, etc. In the second phase (2003-2010) topics like implementation problems, time consumption, checklist and political will fetch more attention than those considered in the first phase.
In the recent years (2011 to 2015),other new topics such as legal system, integrated approach, land policies have emerged while the interest related to amendments, monitoring, guidelines and lack of coordination has remained significantly unchanged.

\begin{tabular}{|l|l|}
\hline $\begin{array}{l}\text { Lack of coordinating } \\
\text { agencies }\end{array}$ & 1 \\
\hline $\begin{array}{l}\text { Amend Plan policies } \\
\text { Standards }\end{array}$ & 1 \\
\hline $\begin{array}{l}\text { New insight to open } \\
\text { spaces }\end{array}$ & 2 \\
\hline
\end{tabular}

\begin{tabular}{|c|c|c|}
\hline \multirow{2}{*}{$\begin{array}{l}\text { No. of } \\
2003-2010\end{array}$} & Inclusiveness & 8 \\
\hline & Transparency & 2 \\
\hline \multirow{6}{*}{ No. of } & Ammendements & 3 \\
\hline & Political Will & 1 \\
\hline & Lack of coordination & 11 \\
\hline & $\begin{array}{l}\text { Issues for } \\
\qquad \begin{array}{l}\text { implementati } \\
\text { on }\end{array}\end{array}$ & 13 \\
\hline & $\begin{array}{l}\text { Process and } \\
\text { Time lag }\end{array}$ & 5 \\
\hline & List & 1 \\
\hline
\end{tabular}

1996-2002
papers
No. of papers
2011-2017
papers

Figure 4. Topic relevance over time

\begin{tabular}{|l|l|}
\hline Ammendements & 9 \\
\hline Lack of coordination & 6 \\
\hline $\begin{array}{l}\text { Time Consuming } \\
\text { Process }\end{array}$ & 15 \\
\hline $\begin{array}{l}\text { Community } \\
\text { Involvement }\end{array}$ & 3 \\
\hline Monitoring & 5 \\
\hline Guidelines & 3 \\
\hline Urban Act Commission & 3 \\
\hline Land Policies & 5 \\
\hline $\begin{array}{l}\text { Implementation } \\
\text { Problems }\end{array}$ & 15 \\
\hline Legal System & 5 \\
\hline Integrated Approach & 16 \\
\hline
\end{tabular}

(Ref. Alexandra Lagorio, 2016)

Note: Grey background =new topics addressed during the studied period

\section{MAIN RESEARCH METHODOLOGIES USED AND RELATIONSHIP TO KEY TOPICS}

Besides the research methodology, consideration of the data typology and analysis is relevant. The research therefore made a distinction between qualitative and quantitative data.
Quantitative data can be measured and checked, and can be skewed by statistics. Qualitative data, such as stakeholder views, are not explicitly observable. Quantitative data, more precisely, determines, whereas qualitative data explains. Overlapping of data aids to study and examine the

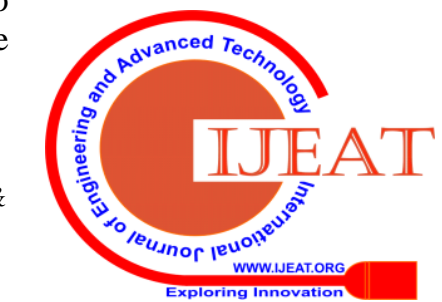




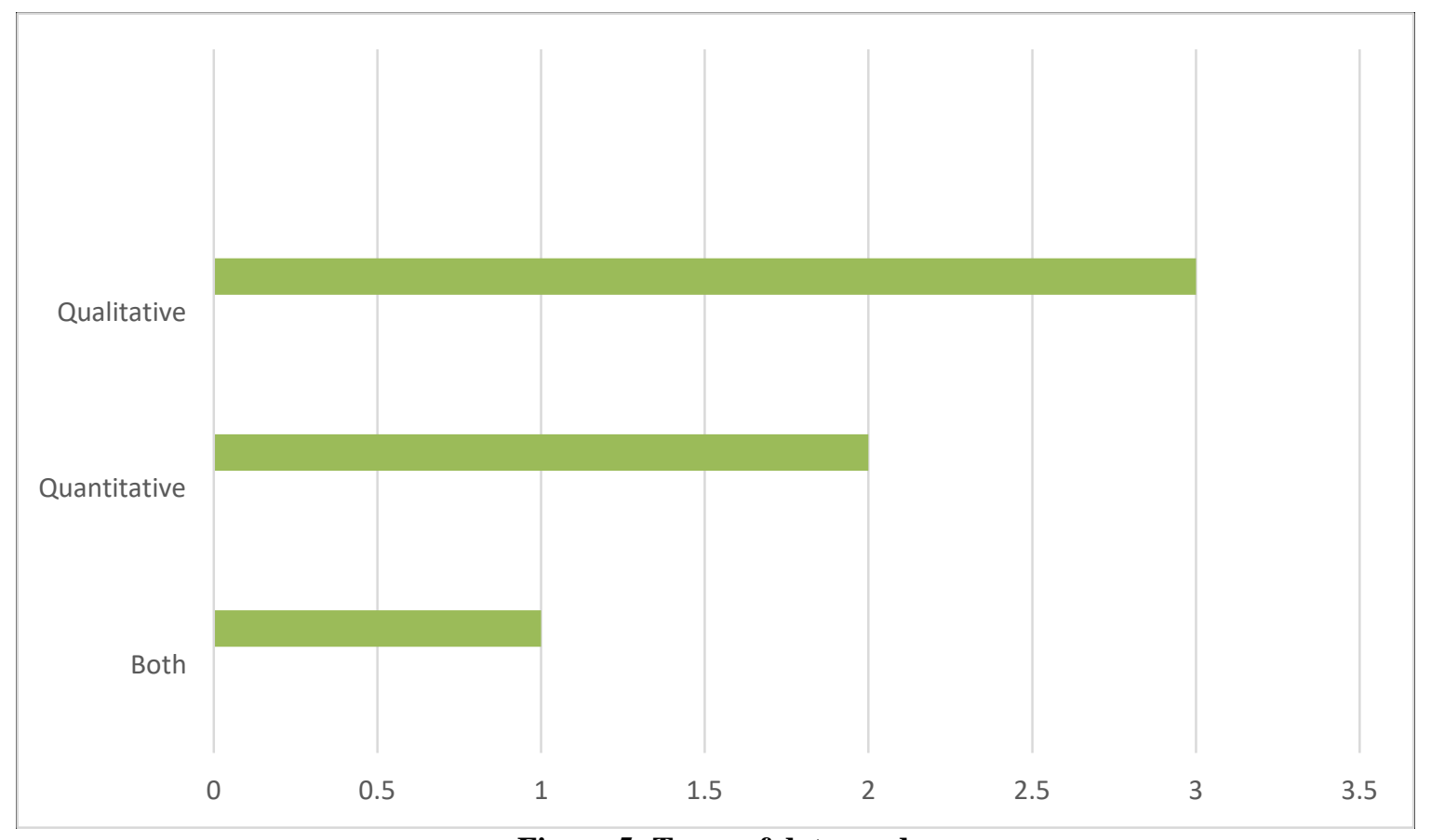

Figure 5: Types of data used

\section{MAIN CONTRIBUTION DRIVING THE DEVELOPMENT OF THE LITERATURE}

The citation of some paper are mentioned with reference to the 131 papers from the pool. The articles considered as important contribution to the field are those that have received several quotes from other authors. Table III focuses on a few frequently cited articles.

Table III: Documents frequently cited in the corpus

\begin{tabular}{|c|c|c|c|}
\hline Reference of Title & Writers & Year & Citation \\
\hline Eco -cities : Global Survey 2009 & Simon joss & 2010 & 44 \\
\hline $\begin{array}{l}\text { Urban planning, community involvement, and Master Plan } \\
\text { Roxboury in Bost }\end{array}$ & James Jennings & 2004 & 41 \\
\hline $\begin{array}{l}\text { Formulation of checklist for implementation planning } \\
\text { guidelines }\end{array}$ & Gagliardi A. et.al. & 2015 & 27 \\
\hline $\begin{array}{l}\text { Reviewing the link of theory and planning practice of } \\
\text { planning }\end{array}$ & $\begin{array}{l}\text { Ahmed Baha El deen } \\
\text { Abukhatar }\end{array}$ & 2009 & 20 \\
\hline $\begin{array}{l}\text { Implementation of urban master plans challenges: The } \\
\text { Lahore experience. Production, dated 55, } 13510 .\end{array}$ & Hameed,R.,\&Nadeem,O. & 2006 & 16 \\
\hline $\begin{array}{l}\text { Rethinking urban planning in India: Learn from the wedge } \\
\text { between Mumbai's de jure and de facto } \\
\text { development. Cities, 39, 120-132. }\end{array}$ & Nallathiga, R.et.al & 2014 & 14 \\
\hline $\begin{array}{l}\text { Country land use planning opportunities and problems in the } \\
\text { Intermountain West. Journal of Extension, 41(5), } 5 \text {. }\end{array}$ & McLeod, D et.al & 2003 & 10 \\
\hline
\end{tabular}




\begin{tabular}{|c|c|c|c|}
\hline $\begin{array}{l}\text { What happens to urban planning and town design? Musings } \\
\text { about the perceived discrepancy between theory and } \\
\text { practice. City, Territory and Architecture, 1(1), } 7 \text {. }\end{array}$ & Palermo, P. C & 2014 & 7 \\
\hline $\begin{array}{l}\text { From master plan to vision plan: the changing role of plans } \\
\text { and strategies (referring to Mumbai) in urban } \\
\text { development. Theoretical and Empirical Researches in } \\
\text { Urban Management, (13), } 141 .\end{array}$ & Nallathiga, R. & 2009 & 7 \\
\hline $\begin{array}{l}\text { Perception of planners on factors that affect the } \\
\text { implementation of the Plan in Iskandar } \\
\text { Malaysia. International Journal of Built Environment and } \\
\text { Sustainability, 2(1). }\end{array}$ & Johar, F et.al. & 2015 & 6 \\
\hline $\begin{array}{l}\text { Politics to implement urban plans in India: Pune's } \\
\text { development plan case. International development planning } \\
\text { review, 24(1), 77-103. }\end{array}$ & Kulabkar, P. & 2002 & 6 \\
\hline
\end{tabular}

A review and analysis of chronological analysis of selected papers provides structural backbone of the

1996-23.Ministry of Urban Affairs and Employment, Govt. Of India, New Delhi 2001-8.Deborah Thomas

2002-1.Catharine Ward Thompson

2003 7.Donald McLeod, Roger Coupal, Andrew Seidl, Katherin 17.Pettit,ChristopherJames. 2005-14. Dejene Muluget

2006.2. Olivier Toutain \& S.Gopiprasad

2008-20. Yang Li1, Sun Guohui1, Martin J. Eppler

2009 24.Nagpur Vidharbha Builders Association,

3. Chetan Vaidya; 19. Ramakrishna Nallathiga

2010-25. The International Federation of Surveyors (FIG) Copenhagen

26. Shanghai, World Exposition Executive Committee

27. National Development Plan - Uganda

16. Nuriye peker say, Deniz çolakkadioğlu, Sinem özyurt

2011-4. Peter Istvan Balogh,Daniel Takacs

21. Omboi Bernard Messah, Paul Gitau Mucai

2012-12. Tom Goodfellow

2013-6. Afolabi Aribigbola

16. Cristian Anghel

2014 18. Department of the Prime Minister and

Cabinet Ausralia

27. National Development Plan - Ugandda

11. URDPFI Guidelines, 2014

2015-5. Gian Claudia Sciara,

9. Robert Hrelja

10. Maharashtra Government Gazette

11. URDPFI Guidelines, 2014

20. Anna R Gagliardi, Catherine

2016 Urban Development and Housing Dept

Figure 6: Chronology of Literature

Published By:

Blue Eyes Intelligence Engineering \&

nces Publication

(C) Copyright: All rights reserved. 


\section{MAIN RESEARCH ISSUES, GAPS AND FUTURE LINES OF RESEARCH}

The literature review allowed us to recognize some research directions which both academics and practitioners deserve further investigation. A reflective study suggest future research paths based on the evolution of literature.

\section{A Planning and Coordination}

There is a lack of studies analyzing the implementation of urban plans as a whole and a comprehensive question.

Variation in data from various authorities and co-ordination of authorities coming to one consensus creates conflicts in project implementation. (Kanchan Gupta et.al.,2017) Plan execution becomes difficult having many authorities to deal with creating multiple window system resulting delay in the procedure. Need of monitoring effort and its potential to contribute linkages between the higher level policy and its intermediate plans for ultimate outcomes is to be observed (Gian Claudia Sciara). Plan preparation and implementation is a multi-disciplinary and multidimensional activity so planning and coordination is essential for successful implementation of Master Plans. Application of GIS provides integration and user friendly framework for effective execution with

extreme benefits of the information technology, decision making classifications, and simulation models.

GIS can be used at different stages of planning from analysis of existing situations, modelling and projection; selection and development of planning options; plan implementation, evaluation, monitoring, and feedback with scales, functions and sectors of urban planning . Planning activities involves overall administration and development control which can range from a street block, a district ,sub-region of a city to a whole city. Storage , manipulation ,analysis of economical ,social and physical data of a city can be done by GIS. GIS with its techniques, availability of data ,resources and its integration with remote sensing saves time in collecting landuse and environmental information. According to Barnsley and Paulsson (1992), for urban areas remote sensing images help to detect landuse and changes in land use for urban which is an important source of spatial information.

Visualisation of data, display of complex locationallocation models and enhancement of human-computer interaction in the decision- making process as per Armstrong (et al 1986 )and Densham (1994).Thus GIS provides analysis of spatial data with provision of various options and possibilities enhancing entire development and planning process.

\section{$B$ Inclusiveness}

Absence of dovetailing of physical planning with fiscal planning has been largely responsible for lopsided and unplanned growth of our urban areas. Lack of technical capacity, preoccupation with running municipal services and overall lack of will and priority for development affect implementation of the Plan. Need of monitoring effort and its potential to contribute linkages between the higher level policy and its intermediate plans for ultimate outcomes is to be observed. Strategic evaluation of land use change over time is needed (Gian Claudia Sciara, 2015) Investment strategy, communication, and involvement that can carry together approach should be complemented. Involvement by community and stakeholder groups in the plan making process (Pettit, Christopher James,2003). Implication, role and need of Management Information System (MIS) in decision making system needs to be considered.

Similarly Management Information Systems (MIS) provides faster access to required and relevant information for decision making. It provides important input at various stages for making decision. MIS provides relevant information regarding no only decision making but also assists in planning, organizing, monitoring, controlling after implementing. Extensive range of decision alternative depending on the situations, resources and actual site conditions are available. Timely decisions and information is required for making effective implementation.

Similarly Governance not only encourages sustainable and human development but also increases participation and policies functionaries. So the terms MIS, governance and development are closely related in functionaries which helps in bridging the gap in policy formulation and implementation in practice

\section{Implementation problems}

At present implementation occurs in water tight compartments without any horizontal and vertical coordination resulting into violations and unauthorized constructions

(D. S. Meshram,2017) it needs to be adequately supported by creating an effective and efficient machinery, equipped with technical and other managerial skills and powers to see that no deviation from the proposals of Master Plan takes place at ground level. For the effective and efficient implementation of Master Plan proposals, it is necessary to enlist various stake holders for their involvement and cooperation including local bodies and line departments at the time of formulation of Master Plan so that their commitment in the implementation of the plan proposals is ensured. Implementation has received less attention in research than in formulating a strategy. Insufficient implementation strategy leads to inadequate strategy formulation. (Yang Li1.et.al., 2008)

Accountability Processing System (APS) to be developed so as to understand departmental roles and targets, importance of teaming up, desirable actions and captivating ownership of the marks to be achieved.

For ensuring that implementation goes in line with the planning enhancement of trust, transparency and accountability which is measured by Accountability Processing System (APS).To avoid hasty implementations in limited period of time allocated, lack of information and human resources, formulation and control over implementation APS applicability is useful. Accountability and management thus helps in careful handling of the allotted responsibilities and evaluation of performance of tasks assigned with its duration and hurdles in implementation.

Thus the study has provided a review and need for developing effective implementation strategy and policy in the development plan which will be addressed in future research. A meaningful match between what are to be provided immediately priority and what can wait, even it has a premium value in the long run.

Blue Eyes Intelligence Engineering 


\section{CONCLUSIONS}

As discussed at different points in this article, the literature review has several implications for further research: local authorities and their role and coordination with other authorities and politicians. Also leadership and past experience of non-governmental organizations need to be incorporated into the framework considering media important emerging actor.

The aim of this study was to understand the literature and its impact on future research.

Thus GIS, MIS and APS important component of planning support systems and useful to urban planning. They assist in making decisions, enforcement action, increases level of engagement and effectiveness, clear direction and completeness.

Implementation of a Development Plan and improving living and working conditions in city therefore assumes great significance.

\section{REFERENCES}

1. 1 International Theoretical and Research Studies and reports from the Indian Government

2. 2 Shanghai, World Exposition Executive Committee, 2010

3. 3 National Development Plan - Uganda, 2010

4. 4 URDPFI Guidelines, 2014

5. 5 T. \& C.P. Act, 1966

6. 6 Format reference from .Alexandra Lagorio, 2016

7. 7 URDPFI, 2015

\section{AUTHOR'S PROFILE}

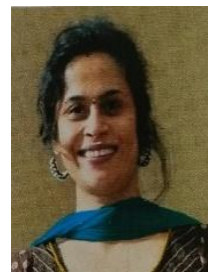

Prof. Rutuja Deshmukh - Jagtap voice: +919850 677517

email: rutujad11@gmail.com

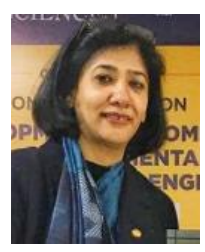

Prof.(Dr.) Ekta Singh

Director, Amity School of Design, Noida

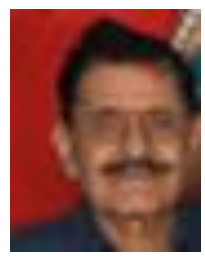

Pramod Shinde, School of Planning \&Architecture, JNIAS,Hyderabad

Email:drpramodsshinde@gmail.com

,India,

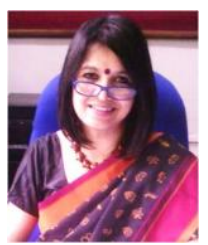

Prof. (Dr.)Aparna Dixit

Professor,

Marathwada Mitramandal's College of Architecture

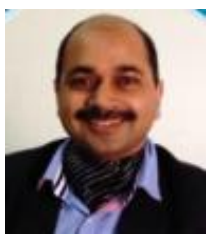

Prof.(Dr.) Devendra Pratap Singh B.Arch (Lko.), M.Arch, PhD (IIT Roorkee) Director- ASAP

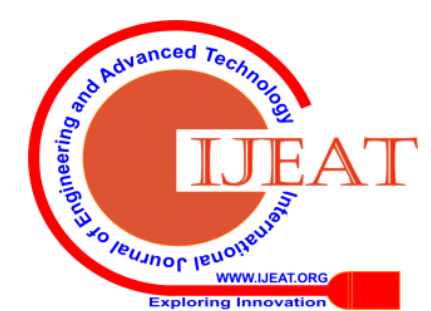

